\title{
Budget Tracking As a Strategy for Sustaining the Fight against Corruption in Nigeria
}

\author{
Dr. Paul Aondona Angahar \\ Department of Accounting, Faculty of Management Sciences, Benue State University .Makurdi
}

\begin{abstract}
This paper has examined budget tracking as one of the possible strategies for fighting corruption in Nigeria to promote resource management for sustainable development and it is based on a conceptual analysis that is largely dependent on a literature review. Budget tracking, also referred to as resource flow tracking is very important in the management of public funds because the approved financial resources meant for specified programmes normally pass through many stages of government bureaucracy before getting to the ultimate service facilities that are set up to exercise spending power. Budget tracking is undertaken in tandem with the two major components of budgets; accordingly, there is revenue tracking and expenditure tracking. Revenue tracking begins immediately with budget implementation; it seeks to develop government capacity to translate budget intensions into reality. It is concerned with ensuring that all budgeted revenues are diligently collected and fully remitted into government coffers. In Nigeria the correct practice is that all revenues collected on behalf of government are must be first paid into the Consolidated Revenue Fund (or Treasury) before obtaining allocations for the recurrent and capital spending. Many Ministries, Departments and Agencies (MDAs) of government in Nigeria do not remit revenues collected by them to the treasury, yet their recurrent and capital spending needs are fully appropriated. Budget tracking can be employed as one of the strategies for sustaining the fight against corruption. Nevertheless, before this strategy can be gainfully employed in the fight against corruption, the legislature must rise and surmount the challenges that confront and hinder them from performing their constitutional duty of budget tracking.
\end{abstract}

Key words: Budget tracking, Accountability, Revenue tracking, Expenditure $\quad$ tracking, Legislature.

\section{Introduction}

The manifestations of corruption in its various facets resulting from a long period of public governance failure in Nigeria has retarded the economic growth and development of the country, it has diminished the status of the country among the comity of nations.

Transparency International's Corruption Perceptions Index (CPI) is the world's most credible measure of domestic public sector corruption. The 2013 CPI scores countries on a scale of zero to 100, with zero indicating high levels of corruption and 100 low levels. The 2013 CPI score for Nigeria is 25 and the country ranked, as the $144^{\text {th }}$ out of 177 countries, in other words, it is the $33^{\text {rd }}$ most corrupt country in the world.(Transparency International)

Corruption is majorly responsible for Nigeria's classification among the poorest countries of the world despite its enormous human and natural resources. Corruption in Nigeria has become a hydra headed monster, a lot has been said and written about corruption yet it continuous to wax stronger, most noticeably in the public sector of the economy. There is the need to fight corruption so that Nigeria can properly harness and manage her resources for sustainable development.

To fight corruption in Nigeria a single strategy or tool is not enough to stem its tide, a multiplicity of strategies have to be adopted (Akpa, 2007:2).

It is in the context of the preceding that this paper is aimed at examining budget tracking as one of the possible strategies for fighting corruption in Nigeria. In order to attain this overall objective, the rest of the paper is organized and presented around the following related themes:

$\checkmark$ Conceptual considerations of budget tracking and corruption.

$\checkmark$ Budget tracking and the fight against corruption.

$\checkmark$ Challenges confronting budget tracking in Nigeria.

$\checkmark$ Conclusion.

\section{Conceptual considerations of budget tracking and corruption}

Budget tracking is a system that allows stakeholders to see more clearly, where money is coming from and where it is being spent (Gurowa, 2011:18).

Budget tracking, also referred to as resource flow tracking is very important in the management of public funds because the approved financial resources meant for specified programmes normally pass through many stages of government bureaucracy before getting to the ultimate service facilities that are set up to 
exercise spending power. Resource tracking determines the quantum of the originally allocated resources that actually reach service levels and the amount that get lost in the process. Through tracking, the resources are followed, wasteful spending and corruption prevented, and value for money maximized. Consequently, it is a tool that can help in preventing unwholesome instances of unspent votes not remitted to the treasury at the end of the fiscal year (Akpa, 2009:6). Effective budget tracking is thus a strategy that can be employed for enforcing accountability, transparency, fiscal discipline, and due process of law and as a result stemming the tide of corruption (Agere and Mendoza, 1999:5).

Government resources allocated for particular uses flow within a legally defined institutional framework. Funds often pass through several layers of government bureaucracy on the way to service facilities, which are charged with the responsibility of exercising the spending. Policymakers in developing countries seldom have information on actual public spending at the provider or facility level or by activity. A public expenditure tracking survey (PETS) tracks the flow of resources through these strata, on a sample survey basis, in order to determine how much of the originally allocated resources reach each level. It is therefore useful as a method for locating and quantifying political and bureaucratic capture, leakage of funds, and problems in the deployment of human and in-kind resources, such as staff, textbooks, and drugs (Reinikka and Svenson 2011:3). Public expenditure tracking involves tracing the flow of public resources for the provision of public goods or services from origin to destination. It can help to detect bottlenecks, inefficiencies, and/or corruption in the transfer of public goods and resources and ensure that allocated public resources effectively reach their intended beneficiaries. It can help identify and address problems and weaknesses in systems of public expenditure, transfer and service delivery and it is a key tool for the government and civil society organisations (CSO) to guard against corruption and work towards ensuring transparent, accountable, and effective public financial management. It may involve some form of both quantitative research such as the verification of financial accounts to monitor the actual flow of funds and qualitative research such as interviewing users of public services about their experiences and assessments of the quality, accessibility and cost of public services. It is possible to undertake expenditure tracking at all tiers of government (Melena, 2011:1).

The legal and operational definition of corruption varies with countries. Transparency International (TI) defines corruption as "an abuse of entrusted power for private gains." Hence, this definition could also cover corruption in the private sector. (Campos and Pradham 2007:22).

Corruption defined as the diversion of public resources for private use can affect operations, at the level of the federal, state and local government administrations.

Corruption can be distinguished by the amount involved (petty or grand), the function or responsibilities of the persons involved (politicians, civil servants), or the institutions (executive, parliament, judiciary). The negotiation and implementation of large-scale projects provide a fertile ground for political corruption. Administrative corruption takes the form of petty corruption (small bribery, theft of cash, goods and services, etc.); direct abuse of public office (misuse of public financial and real assets, illegal fines, taxes, contract steering, twisting of rules, cronyism and nepotism, etc.); and indirect abuse of public office (bribe for favorable treatment or ruling). Administrative corruption generally takes place at the tail end of politics where public officials encounter the public at large (Doe, 2007:6).

Public accountability pertains to the obligations of persons or entities entrusted with public resources to be answerable for the fiscal, managerial and programme responsibilities that have been conferred on them, and to report to those that have conferred these responsibilities (Boncondin, 2007:8).

From the above definition of public accountability, it is apparent that the public entities that utilize public resources have an obligation to account for the way these resources are allocated, used and the results that these expenditure have achieved. In other words, the main objectives of all public accountability initiatives are to ensure that public money is spent most economically and efficiently, that there is minimum of wastage, theft or corruption and finally that the public actually benefits from public finance.

In response to these accountability requirements of public sector spending, most governments have put in place various expenditure tracking and reporting systems (Khan and Chowdhury 2011:1).

\section{Budget tracking and the fight against corruption}

Government budget should cover all government operations namely current and capital, quasi-fiscal operations, extra-budgetary operations, and all receipts (Doe, 2007:4). Budgets, thus consists of two major components -the revenue and the expenditure. Budget tracking is undertaken in tandem with the two major components of budgets; accordingly, there is revenue tracking and expenditure tracking.

Revenue tracking begins immediately with budget implementation; it seeks to develop government capacity to translate budget intensions into reality. It is concerned with ensuring that all budgeted revenues are diligently collected and fully remitted into government coffers. In Nigeria the correct practice is that all revenues collected on behalf of government are must be first paid into the Consolidated Revenue Fund (or Treasury) before obtaining allocations for the recurrent and capital spending. Many Ministries ,Departments and 
Agencies(MDAs) of government in Nigeria do not remit revenues collected by them to the treasury, yet their recurrent and capital spending needs are fully appropriated either from the federal or state budgets. The nonremittance to the treasury of revenues collected is a corrupt practice; it implies misappropriation (Akpa 2009:2).

Expenditure tracking aligns available resources with the budgeted goals, in addition, in the process, it determines whether the expenditure really went to the items or people identified as targets in the budget, it insists on exposing the misapplication of resources. Expenditure tracking investigates whether the funds released reached the frontline service providers, where there is a leakage problem it can be blocked. Misapplication of resources and leakages are all acts of corruption that can be checked through expenditure tracking.

The constitution of Nigeria empowers the legislature to conduct budget tracking. Section 100(1) of the 1999 constitution of the Federal Republic of Nigeria mandates the state houses of assembly to make laws for the good governance of the state and to see to it that all laws made by it including the appropriation law are properly implemented. Section 128(2) empowers the legislature to take appropriate steps in its investigative functions to expose instances of corruption, in-efficiencies and waste in the use of financial resources approved by the legislature. It is through the legislative power to appropriate funds for the execution of government policies, programmes and supervise activities of the executive arm that the masses can keep track of government budget and prevent incidences of corruption.

\section{Challenges confronting budget tracking in Nigeria}

The ability of the legislature to effectively perform its constitutional role of budget tracking permitted by the 1999 constitution, is confronted with serious challenges that hinder the effective use of budget tracking as a strategy for sustaining the fight against corruption in Nigeria, these challenges are enumerated seriatim:

$\checkmark \quad$ There is the absence of a well-developed financial system for timely tracking and reporting, this is because there is the lack of reliable and complete information on the profile of revenues and expenditures in government in Nigeria.

$\checkmark$ Nigerian legislators hardly possess the experience of the executive arm of government and they are handicapped by dependence on the executive branch for resources.

$\checkmark$ Corruption within the legislature itself, the legislature instead of performing its constitutional role has often sold its conscience by collecting gratification from the executive arm of government. Members of several state houses of assembly have collected 'gifts' in form of automobiles from there executive governors and consequently failed to perform their budget tracking functions with dedication.

An instance of corruption by Nigerian legislature, it was reported that to induce Parliament to change the constitution to enable him to remain in power, the former President Obasanjo is alleged to have offered 50 million naira (about \$390,000) to each legislator. The Presidency denied the allegation (Doe, 2007:24).

$\checkmark$ Apart from outright corruption within the legislature, the inability of the legislators to resist the carrots dangled by executives such as sitting of projects within their constituencies or granting them other favours has played a key role weakening the ability of members of parliament to actively perform their role of tracking the budget and preventing executive corruption.

$\checkmark \quad$ In advanced jurisdictions, budget tracking and oversight functions are full time activities undertaken by professionals who employed to collect and process all necessary information for such purpose. In Nigeria budget tracking is yet to be recognized as a professional activity and time devoted to budget tracking and oversight activities is rather very short.

$\checkmark$ Budget requests from MDAs in Nigeria is often made and approved without a detailed logistic framework and time schedules for implementation, making it rather difficult to monitor implementation and consequently enormous difficulties for tracking.

$\checkmark \quad$ The full implementation of the recently adopted international public sector accounting standards will assist in revenue and expenditure tracking at all levels of government. The full implementation of these standards is a challenge that has to be taken seriously.

\section{Conclusion}

Corruption has dealt a devastating blow to Nigeria's economic growth and development, It is responsible for the high rate of unemployment in the country and current instability in the country. In the fight against corruption, no strategy or weapon should be spared, if the country is to get out of the current dismal situation it faces. In the fight against corruption, effective budget tracking can be employed as one of the strategies for sustaining the fight against corruption. Nevertheless, before this strategy can be gainfully employed in the fight against corruption, the legislature must rise and surmount the challenges that confront and hinder them from performing their constitutional duty of budget tracking. If they overcome these challenges and live up to their responsibilities, Nigeria will be better off. 


\section{References}

[1]. Agere, P. and Mendoza,S.(1999). Planning and Budgeting for efficient Economic Management. A National workshop report Ibadan.NCEMA.pp1-27

[2]. Akpa, A.(2007). Sustained Fight Against Corruption As a Key to Meaning Rural Development in Nigeria. Paper Delivered at a Seminar organized by the Senate Committee on Local Governments, Held at Ibro Hotel, Abuja $5^{\text {th }}-7^{\text {th }}$ May .pp1-13

[3]. Akpa, A.(2009). Strengthening Budget Tracking by the Legislature as a Response to Global Economic crisis: Adding Value to Good Governance through Oversight Monitoring. Paper Members of The Benue State House of Assembly in collaboration with ALCimage Consult Ltd on Budgeting Process, Monitoring and Oversight Functions of the Legislature at Protea Hotels, Abuja, April 14.. pp1-12

[4]. Boncondin, E.T.(2007). "Citizen Engagement in Budgeting and Public Accountability" paper presented at the 6th Session of the United Nations Committee of Expert on Public Administration., United Nations HQs, New York. April 10-14, pp1-21

[5]. Campos, J.E and Pradham, S. (Ed)(2007). The Many Faces of Corruption:Tracking Vulnerability at the Sector Level. World Bank. pp1-53 Doe, L.(2007) .

[6]. Public Financial Management and Corruption. Joint Africa Institute Seminar on the Role of Parliamentarians in Promoting Good Public Financial Management and Accountability in Africa. Tunis, November 19-23,pp1-26

[7]. Federal Republic of Nigeria (1999). The Constitution. Lagos: Federal Government Printer.

[8]. Gurowa, S.(2011). The Effect of Expenditure Tracking on Quality of Public Education Service Delivery in Nigeria: A study of Universal Basic Education Commission in North-Central Zone of Nigeria. A Ph.D (Accounting and Finance) thesis, Benue State University, Makurdi. pp1-183

[9]. Khan, M.A and Chowdhury, M.(2011). Public Accountability,corruption control and service delivery: governance challenge and future options. United Nations Research Report. pp 1-10 Melena, C.(2011). Public Expenditure Reporting and Tracking. CIVICUS Participatory Governance Programme 2011 pp $1-4$

[10]. Reinikka ,R. and Svenson,J.(2011) Survey Techniques to Measure and Explain Corruption. Institute for International Economic Studies, Stockholm University.2011 pp 1-21

[11]. Transparency International (2014).Corruption Perceptions Index(CPI). Retrieved from www.transparency.org/cpi on 25/8/2014 